\title{
Assessment of climate change impact on high flows in a watershed characterized by flood regulating reservoirs
}

\author{
Sabin Shrestha ${ }^{1}$, Suresh Sharma ${ }^{2 *}$ \\ (1. Civil and Environmental Consultants, Inc., Bridgeport, WV 26554, USA; \\ 2. Civil/Environmental Engineering Program, Youngstown State University, One University Plaza, Youngstown, \\ $\mathrm{OH} 44555, \mathrm{USA})$
}

\begin{abstract}
A climate-induced extreme flow event such as flooding is one of the most devastating natural hazards, which can significantly damage human lives and properties. This study examined the effects of climate change on the high flow conditions in the Great Miami River Watershed in Ohio under two emission scenarios (RCP 4.5 and RCP 8.5). Streamflow for the 21 st century was simulated by utilizing a watershed model - SWAT (Soil and Water Assessment Tool) and 10 different climate outputs from the Coupled Model Intercomparison Project phase 5 (CMIP5). The future streamflow was divided into three equal periods: 2016-2043 (early century), 2044-2071 (mid-century), and 2072-2099 (late century) and independently analyzed to compare high flows of respective intervals with baseline periods (1988-2015). The analysis predicted that 7-day, 10-year high-flow (7Q10) would increase by $38 \%$ under RCP 4.5 and 44\% under RCP 8.5. Similarly, the annual peak flows for study periods were predicted to increase by $26 \%$ under RCP 4.5 and $38 \%$ under RCP 8.5 from the base period. However, the analysis demonstrated an erratic response for monthly peaks indicating that the peak flow would increase in summer months - May and July to October. Meanwhile, the result did not show any significant increase during the winter season, especially from November to April. The analysis of the four major dams located in the watershed showed that the dam's peak discharges increase in January, May, and September. Even though increasing peaks were projected in September for the 21st century, the monthly peaks from the watershed outlet were found to be lowest in September as compared to other months. The frequency of future flooding compared to the historical record was found to be increasing in the mid-century under RCP 4.5 and the late century under RCP 8.5. As the future flood is projected to increase, this study finds the reasonable impact of climate change on flood regulating reservoirs/dams in monthly flows. However, daily high flows (90th percentile flow) would be increasing significantly ( $44 \%$ to $250 \%$ ) under RCP 8.5 .
\end{abstract}

Keywords: climate change, high flows, SWAT, Great Miami River Watershed, flood regulating reservoir, assessment DOI: $10.25165 /$ j.ijabe.20211401.5883

Citation: Shrestha S, Sharma S. Assessment of climate change impact on high flows in a watershed characterized by flood regulating reservoirs. Int J Agric \& Biol Eng, 2021; 14(1): 178-191.

\section{Introduction}

Climate change can alter the hydrologic cycle and may have negative effects on water resource availability and sustainability ${ }^{[1,2]}$ Human activities are responsible for altering the global atmospheric composition including greenhouse gases to accelerate anthropogenic climate chang $\mathrm{e}^{[3-5]}$. As a result, significant changes in temperature and precipitation are expected in the 21 st century ${ }^{[6]}$. An increasing amount of greenhouse gas concentrations in the atmosphere causes subsequent global warming and changes the Earth's hydrologic cycle in multiple ways over different geographic regions at various temporal scales ${ }^{[7]}$. Such changes in the hydrological cycle lead to more precipitation and extreme rainfall, which eventually results in increased runoff and flood risks ${ }^{[8]}$.

\section{Received date: 2020-05-03 Accepted date: 2020-09-22}

Biographies: Sabin Shrestha, MS, Researcher, research interest: analysis and evaluation of hydraulic and hydrologic systems under climate change, assessment of climate models and quantify the model uncertainties and capacity to predict extreme flows, floodplain modeling, Email: sshrestha01@ student.ysu.edu.

*Corresponding author: Suresh Sharma, Associate Professor, research interest: hydrology and water quality modeling. Civil/Environmental Engineering Program, Youngstown State University, One University Plaza, Youngstown, OH 44555, USA. Tel: +1-330-941-1741, Email: ssharma06@, ysu.edu.
Several studies in the past have reported the changes in hydrological regimes due to climate change using large-scale hydrological models ${ }^{[9-12]}$.

Researches from all over the world including the United States have shown that the average streamflow is projected to increase in the future ${ }^{[9,10,13-17]}$. Increased flood risk in the future due to climate change is also reported in various research articles ${ }^{[18-24]}$. Similarly, extreme rainfall events and flooding in the Midwest USA, where this study area is located, have increased during the last century up to $20 \%$ in some locations ${ }^{[25]}$. The increasing trend of precipitation in the Midwestern USA is reported by various scientists $^{[26-32]}$.

Furthermore, the impacts of climate change in streamflow were investigated in various watersheds of the Midwestern United States ${ }^{[16,33-38]}$. A study conducted by Milly et al. ${ }^{[39]}$ in 2005 who utilized an ensemble of 12 climate models, showed that total runoff is expected to increase by $10 \%-40 \%$ in high-latitude North America by the end of 2050. In the Midwestern United States, flooding occurred in 2008 after months of extreme precipitation causing 24 deaths and damage of billions of dollars in terms of agricultural products and disruption of transportation systems ${ }^{[40]}$. Therefore, it is crucial to assess the extreme storm events and high flows due to climate change in order to mitigate its impacts and build a resilient society.

The impact of climate change on hydrology is typically conducted 
using climate data in a hydrological model or a watershed model. For example, Soil and Water Assessment Tool (SWAT) model has been widely used to study climate change impact on streamflow $^{[15,17,19,22,41-47]}$. Although studies related to climate change impact were conducted in the past, the vast majority of the studies were focused on the average increase in streamflow. Studies exploring whether or not the flood regulating reservoirs capable to serve the purpose of retaining the increased runoff in the future due to climate change were reviewed ${ }^{[48-54]}$. Nonetheless, there were limited studies conducting a comprehensive analysis of extreme high flows in a watershed, where flood protection reservoirs are primarily developed. Moreover, based on our review, no adequate studies have been conducted exploring the comprehensive investigation of high flows in the watershed in the Midwest USA.

In order to investigate the impacts of climate change on extreme events such as future flooding, projected climate models have been developed from the Global Circulation Models $(\mathrm{GCMs})^{[55,56]}$. Many studies in the past examined the impacts of future climate projections downscaled from GCM simulations on water resources ${ }^{[13,18,34,57]}$. The major focus of this study is to predict the impact of climate change based on 10 climate models from CMIP5 dataset and two greenhouse gas emission scenarios RCP 4.5 and RCP 8.5 using a widely accepted watershed model, SWAT. As a case study, the Great Miami River Watershed was selected to explore the responses of climate change on high flows.

\section{Methods}

\subsection{Study area}

The Great Miami River is one of the major tributaries of the Ohio River, which drains approximately $10023 \mathrm{~km}^{2}$ in southwestern Ohio including $224 \mathrm{~km}^{2}$ in Indiana. Great Miami River originates from Indian Lake in Logan County, Ohio and flows southwest approximately $274 \mathrm{~km}$ before emptying into the Ohio River near Cincinnati. The Great Miami River watershed surrounds a portion of Ohio and Indiana extending within the latitude of $39.15^{\circ} \mathrm{N}$ to $40.64^{\circ} \mathrm{N}$ and longitude of $83.55^{\circ} \mathrm{W}$ to $84.9^{\circ} \mathrm{W}$. The elevation of the watershed ranges from $140.6 \mathrm{~m}$ to $471.4 \mathrm{~m}$ with an average hillslope of $2.86 \%$. The 36-year (19802015) average annual precipitation for the entire watershed was $1035 \mathrm{~mm}$ and the average maximum and minimum temperature were $16.65^{\circ} \mathrm{C}$ and $5.28^{\circ} \mathrm{C}$, respectively. The vast majority of the watershed is covered by agricultural land (70\%) and urbanized area (18\%) followed by forest $(11 \%)$, and water bodies and wetlands (1\%). Readers can refer to Shrestha et al. for detail spatial information and description of the watershed ${ }^{[58]}$.

All major cities in the watershed are situated close to the Great Miami River and its tributaries. Consequently, these cities are more vulnerable to increased river flooding in the Miami River. The watershed has already experienced several destructive flood events in the past. For example, the great flood of 1913 which was occurred due to heavy snowmelt and intense precipitation that overflowed the Great Miami River as well as its tributaries. The aftermath of this flooding incurred losses of over 300 lives and property damages of $\$ 2$ billion worth in today's currency ${ }^{[59]}$. Thus, flooding is still considered to be one of the biggest challenges in the Great Miami River watershed. The watershed has 2 natural lakes (Indian and Loramie) and 6 major artificial dams (Clarence J Brown Dam, Englewood Dam, Germantown Dam, Huffman Dam, Lockington Dam, and Taylorsville Dam). These dams were built primarily as flood protection reservoirs to store floodwater, especially after heavy and prolonged storm events.

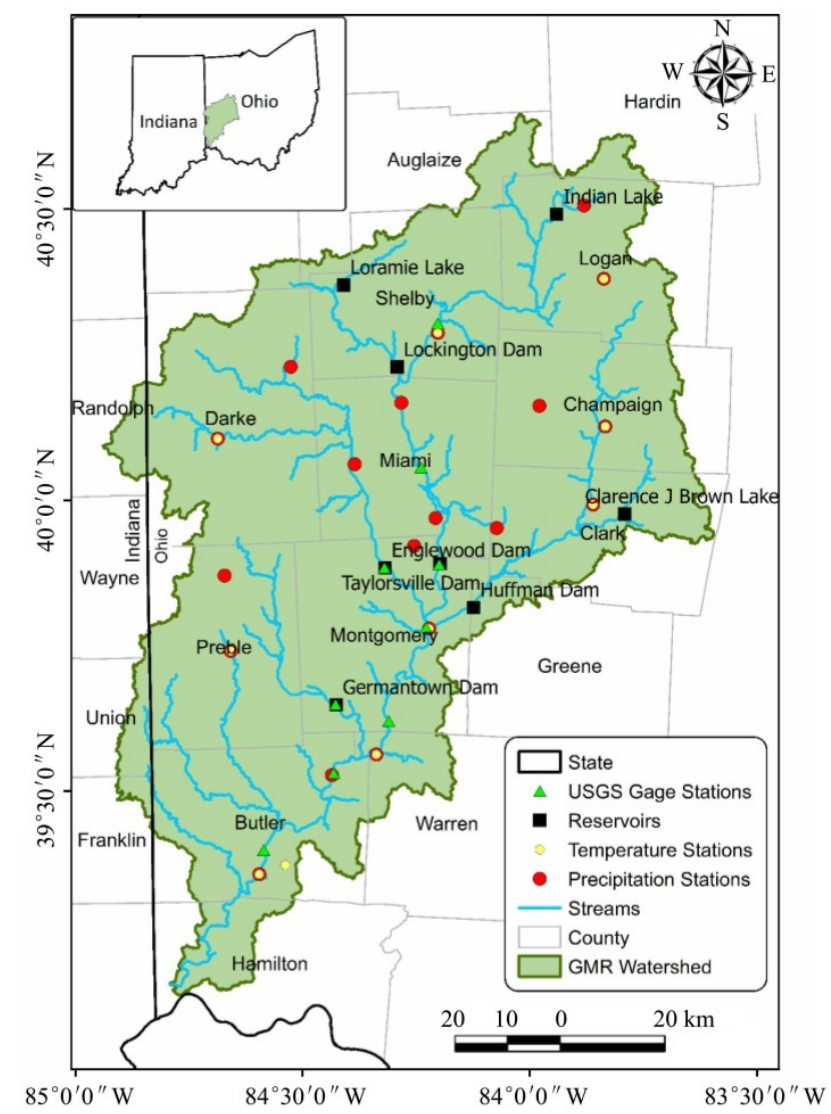

Figure 1 Location of USGS gage stations, climate stations, and reservoirs/dams in the Great Miami River Watershed, OH, USA

\subsection{SWAT model inputs}

The spatial and hydrological inputs used in SWAT model simulation consist of Digital Elevation Model (DEM), land-use land cover data, soil type, and climate data. A 30-m DEM obtained from USGS National Elevation Dataset was used to delineate the Great Miami River watershed with 114 sub-basins. Seven reservoirs and 28 major point sources were added to the respective sub-basins while delineating the watersheds. Reservoirs data including maximum discharge, storage capacity, and drainage area were obtained from the Miami Conservancy District and the United States Army Corps of Engineers (USACE). Point sources data from wastewater treatment facilities and other industries were downloaded from the Ohio Environmental Protection Agency (OEPA). The National Land Cover Dataset of 2011 and STATSGO soil data from USDA have been utilized for land-use and soil, respectively to create hydrologic response units (HRUs). The watershed was then discretized into 2676 HRUs using the threshold values of $5 \%, 15 \%$, and $15 \%$ for land-use, soil, and slope, respectively.

The daily climate data for 36 years (1980-2015) from the National Climatic Data Center (NCDC) were applied in the model (Figure 1) from 19 climate stations. Other meteorological data such as humidity, solar radiation, and wind speed were incorporated from a weather generator tool built-in SWAT model.

\subsection{Reservoir simulation in SWAT}

Reservoirs are the structures in a watershed that collect water and store it for some time. SWAT treats the reservoir as a water body located on the stream network of the watershed. Any water bodies located outside of the main channel network are considered as ponds. The water balance equation for each reservoir 
comprises five major hydrologic components: inflow, outflow, precipitation, evaporation, seepage from the reservoir, and diversions (Equation (1)). The outflow from a subbasin, where the reservoir is situated, becomes the inflow for the reservoir. The evaporation, seepage, and precipitation volumes depend on the surface area of the waterbody in the reservoir.

$$
V=V_{\text {stored }}+V_{\text {flowin }}+V_{\text {pcp }}-V_{\text {flowout }}-V_{\text {evap }}-V_{\text {seep }}
$$

where, $V$ is the volume of water stored in the reservoir at the end of the day, $\mathrm{m}^{3} ; V_{\text {stored }}$ is the volume of water stored in the water body at the beginning of the day, $\mathrm{m}^{3} ; V_{\text {flowin }}$ is the volume of water entering the water body during the day, $\mathrm{m}^{3} ; V_{\text {pcp }}$ is the volume of precipitation falling on the water body during the day, $\mathrm{m}^{3} ; V_{\text {flowout }}$ is the volume of water flowing out of the water body during the day, $\mathrm{m}^{3} ; V_{\text {evap }}$ is the volume of water removed from the water body by evaporation during the day, $\mathrm{m}^{3} ; V_{\text {seep }}$ is the volume of water lost from the water body by seepage, $\mathrm{m}^{3}$.

The SWAT model has four options to estimate the outflow volume from the reservoir. The first option is executed by using the average annual release rate, which is best suited for small and uncontrolled reservoirs. The second option is executed by specifying a controlled target release of the reservoir, which is designed for larger and managed reservoirs. Option three and four require time-series data of daily outflow and monthly outflow from the reservoir. Further details can be found in the SWAT theoretical documentation ${ }^{[60]}$. For this study, outflow simulation for the reservoir was performed by the average annual release rate. The average daily principal spillway release rate was provided in the SWAT model.

\subsection{Model calibration and validation}

The SWAT model was run to simulate streamflow for 28 years (1988-2015) in daily time steps, with a 3-year warm-up period (1985-1987). SWAT model was calibrated and validated using daily observed streamflow data at nine USGS gage stations, which were spatially distributed within the watershed. The simulation period was divided into two separate periods for calibration and validation each comprising 10 years. The model calibration was carried out by using flows from 2005 to 2014, whereas validation was accomplished using independent datasets from 1995 to 2004, which was not utilized for model calibration.

Calibration of the model was accomplished both manually as well as automatically using SWAT-CUP ${ }^{[61]}$. The model simulated flow hydrographs were compared against the observed flow hydrographs by using statistical measures as well as through the visual inspection by comparing high peaks and low flows of simulated with observed flows. In the next step, model calibration was performed using Sequential Uncertainty Fitting version 2 (SUFI-2) in SWAT-CUP, which works under a semi-automatic inverse modeling procedure algorithm ${ }^{[61]}$. Various SWAT model parameters, reasonably appropriate in this region based on the climate and land-use characteristics, were selected for the calibration process. The suggested parameters from SWAT-CUP were utilized for model validation.

\subsection{Model evaluation criteria}

The performance of the SWAT model was evaluated by using four statistical indicators including Nash-Sutcliffe Efficiency $(\mathrm{NSE})^{[62]}$, Percentage Bias (PBIAS), Coefficient of Determination $\left(R^{2}\right)$ and the Ratio of Root Mean Square Error to the Standard Deviation $(\mathrm{RSR})^{[63]}$. The NSE typically varies from $-\infty$ to 1 , whereas $R^{2}$ ranges from 0 to 1 . Model performance is generally considered good provided that the NSE value ranges between 0.5 and $1^{[63]}$. Similarly, a model is considered to be good if the simulated data has a PBIAS value close to 0 . A positive PBIAS indicates the model underestimation, whereas a negative PBIAS represents the model overestimation. Likewise, RSR value 0 indicates the perfect simulated model indicating the close agreement of simulated result with the observed data. Readers can refer to Shrestha et al. for a detailed description of these statistical indicators.

\subsection{Future climate scenarios}

In this study, the projected future climate data (precipitation and temperature) were derived from Global Climate Models (GCMs) based on the Intergovernmental Panel on Climate Change (IPCC), Fifth Assessment Report (AR5). Ten climate models from the Coupled Model Intercomparison Project Phase 5 (CMIP5) have been selected for the simulation of future climate data ${ }^{[64]}$. The CMIP5 climate data were downscaled under four emission scenarios to account for increasing greenhouse gas concentrations as the amount of greenhouse gas is the key variable to climate change ${ }^{[65]}$. The four emission scenarios are Representative Concentration Pathways RCP 2.6, RCP 4.5, RCP 6.0, and RCP 8.5. RCP 8.5 is considered to be the highest emission scenario, whereas RCP 2.6 is the lowest emission scenario. Similarly, RCP 4.5 and RCP 6.0 are two intermediate stabilization emission scenarios. In this study, only two emission scenarios, RCP 4.5 and RCP 8.5 have been applied in the model in order to assess the effects of climate change on streamflow. The CMIP5 climate projection uses the daily Bias Correction Constructed Analogs (BCCA) downscaled technique to obtain finer resolution climate data ${ }^{[66]}$. In order to further fine-tune the downscaled climate data at the local scale, biases present in the data have been additionally corrected utilizing a quantile mapping approach described by Ines and Hansen for precipitation ${ }^{[67]}$ and Li et al. ${ }^{[68]}$ for temperature.

\subsection{Scenario analysis}

10 GCMs and two scenarios of RCP 4.5 and RCP 8.5 of the CMIP5 were utilized. The output from each model includes daily precipitation and temperature (maximum and minimum) for the baseline (1988-2015) and the future periods (2016-2099). The observed datasets of monthly precipitation at Dayton International Airport, OH US (station GHCND: USW00093815) were used to evaluate the model performance. Out of 19 CMIP5 models only 10 models were selected based on their squared correlation coefficients $\left(R^{2}\right)$ for monthly mean precipitations. A climate change study was conducted in Muskingum Watershed, which is near to the Great Miami River Watershed by Sharma et al., 2016 ${ }^{[72]}$ using similar sets of models. To compare the hydrologic conditions from the future to the historical period, the future period from 2016 through 2099 was subdivided into three equal periods: early century, mid-century, and late-century as 2035s (2016-2043), 2055s (2044-2071) and 2085s (2072-2099), respectively.

\subsection{High flows analysis}

The SWAT model was utilized to generate long-term daily streamflow from each subbasin in the watershed. High flows from the simulated and observed discharge at USGS gage station \#03274000 in Hamilton, OH were analyzed (SWAT subbasin 137). In order to evaluate the impact of climate change on high flows, the five high-flows variables were examined by utilizing the ensemble of 10 climate models and 2 emission scenarios in the SWAT model The high-flow variables incorporated in this analysis include 7-day high flows, 7Q10 high flows, annual and monthly peak discharges, $90^{\text {th }}$ percentile flow, and flood frequency analysis with return periods of 2-, 5-, 10-, 25-, 50-, 100-, 200-, and 500-year. The 7 -day high flows are the maximum flow from the average of seven 
days of consecutive flows in a year. Similarly, 7Q10 high flows are defined as the maximum 7-day high flows that have a probability of occurring once in every 10 -year ${ }^{[69]}$. The annual and monthly peak discharges were analyzed to report the extremely high flow events. The PeakFQ program was used for the flood frequency analysis of streamflow data. The PeakFQ program uses Bulletin 17B and Expected Moments Algorithm to estimate flood magnitudes with different recurrence intervals ${ }^{[70]}$. For this, the streamflow series simulated by the SWAT model for $2035 \mathrm{~s}, 2055 \mathrm{~s}$, and 2085 s were separately fed into the program and results were compared against the historical records. The 90th percentile exceedance flows and monthly peak flows were analyzed in the outlet of four major dams located in the watershed based on the SWAT simulated flows from observed climate data (1988-2015) and projected climate data (2016-2099)

\section{Results}

\subsection{Model simulation}

Since the SWAT model was previously set up, calibrated, and validated by Shrestha et al. ${ }^{[58]}$, this study would not provide the detailed model set-up, calibration, and validation processes, but briefly summarize the methods. The SWAT model calibration and validation were performed on a daily and monthly time scale. The model performance was satisfactory during the calibration and validation period with reasonable accuracy, which was assessed through a visual inspection and statistical parameters. The model performance to simulate the daily streamflow in calibration and validation period is shown in Figure 2. The statistical criteria NSE, $R^{2}$, PBIAS, and RSR on a daily and monthly scale from different stations throughout the watershed were $\operatorname{good}^{[58]}$. Additionally, the model performances on high flows were also evaluated by comparing the 75th percentile exceedance from simulated and observed flows. The statistical measures to evaluate the model performance including NSE (0.96), $R^{2}(0.99)$ and Pbias $(-11 \%)$ during the calibration period for 75 th percentile high flows were promising. Similarly, the model performance during the validation period in terms of NSE $(0.93), R^{2}(0.99)$ and Pbias $(-6.8 \%)$ were good.
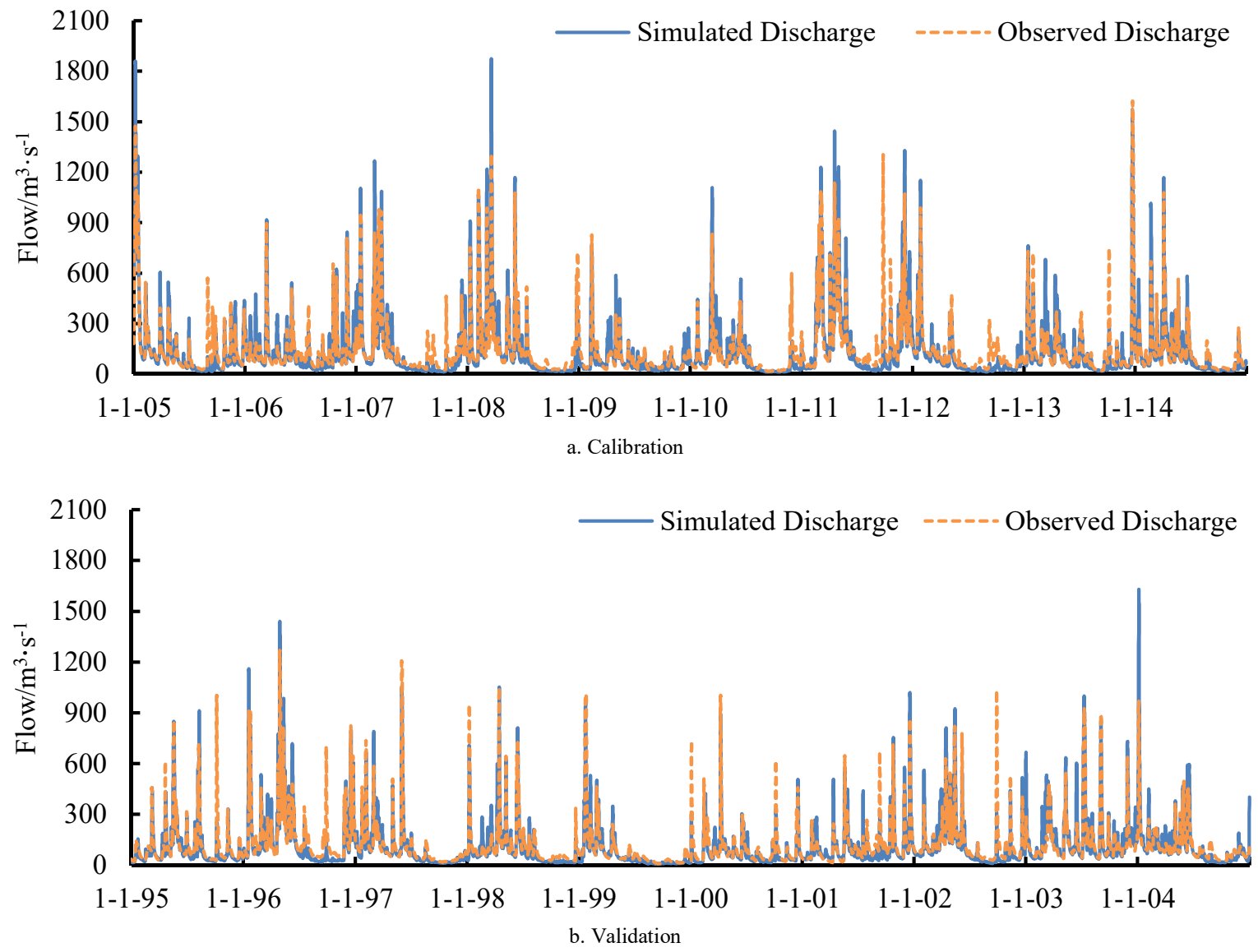

Figure 2 Calibration and validation of daily streamflow at USGS station \#03274000 at Hamilton, OH

\subsection{Change in streamflow}

The simulated streamflow for the entire 21 st century was generated on a daily scale at a subbasin outlet 137 (USGS gage station \#03274000) using 10 CMIP5 climate data in the calibrated SWAT model. The results of average annual streamflow from 10 climate models under two emission scenarios for three reference periods have been presented in Table 1. The annual streamflow recorded at the outlet gage location for the baseline period $(1988-2015)$ was $117.98 \mathrm{~m}^{3} / \mathrm{s}$. The analysis suggested that the streamflow in the Great Miami River would increase in future periods; however, the increasing trends were not consistent through all climate models. Approximately, $77.29 \%$ increase in annual flow was projected from the CSIRO-Mk3.6.0 model under RCP 4.5 in $2085 \mathrm{~s}$, which is the highest increase realized under RCP 4.5 in the analysis. Similarly, the annual average flow would increase by $81.6 \%$ under RCP 8.5 from CANSEM 2 in $2085 \mathrm{~s}$. In general, the predicted annual flow was higher in RCP 8.5 compared to RCP 4.5 for all future periods except using some climate models (MIROC-ESM, CNRM-CM5, CSIRO-MK3-6.5, and CCSM4). Overall, average annual flows were projected to be increasing in later years of the 21 st century (2085s) except using some climate models including MIROC5, CNRM-CM5, and MIROC-ESM. 
Table 1 Change in average annual flows from the ensemble of

10 climate models with respect to the observed streamflow at USGS station \#03274000 under RCP 4.5 and RCP 8.5

\begin{tabular}{|c|c|c|c|c|c|}
\hline \multicolumn{2}{|l|}{ Emission Scenarios } & \multicolumn{2}{|c|}{$\mathrm{RCP} 4.5$} & \multicolumn{2}{|c|}{ RCP 8.5} \\
\hline Models & Period & $\begin{array}{l}\text { Flows } \\
/ \mathrm{m}^{3} \cdot \mathrm{s}^{-1}\end{array}$ & $\begin{array}{c}\text { Change } \\
/ \%\end{array}$ & $\begin{array}{l}\text { Flows } \\
/ \mathrm{m}^{3} \cdot \mathrm{s}^{-1}\end{array}$ & $\begin{array}{c}\text { Change } \\
\quad / \%\end{array}$ \\
\hline Observed (Baseline) & $1988-2015$ & 117.98 & - & 117.98 & - \\
\hline \multirow{3}{*}{ CANSEM2 } & $2016-2043$ & 140.35 & 18.96 & 151.43 & 28.35 \\
\hline & 2044-2071 & 158.67 & 34.48 & 190.42 & 61.40 \\
\hline & 2072-2099 & 162.90 & 38.07 & 214.23 & 81.58 \\
\hline \multirow{3}{*}{ CCSM4 } & 2016-2043 & 157.12 & 33.17 & 153.00 & 29.68 \\
\hline & 2044-2071 & 137.43 & 16.48 & 164.29 & 39.25 \\
\hline & 2072-2099 & 161.00 & 36.46 & 170.38 & 44.41 \\
\hline \multirow{3}{*}{ CNRM-CM5 } & $2016-2043$ & 149.94 & 27.09 & 153.88 & 30.43 \\
\hline & $2044-2071$ & 173.97 & 47.46 & 150.71 & 27.74 \\
\hline & 2072-2099 & 156.26 & 32.45 & 148.15 & 25.57 \\
\hline \multirow{3}{*}{ CSIRO-MK3-6 } & $2016-2043$ & 159.78 & 35.43 & 167.91 & 42.32 \\
\hline & 2044-2071 & 199.53 & 69.12 & 161.74 & 37.09 \\
\hline & 2072-2099 & 209.17 & 77.29 & 197.42 & 67.33 \\
\hline \multirow{3}{*}{ GFDL-ESM2M } & 2016-2043 & 146.51 & 24.18 & 157.71 & 33.68 \\
\hline & 2044-2071 & 171.10 & 45.02 & 181.27 & 53.65 \\
\hline & 2072-2099 & 168.26 & 42.61 & 179.67 & 52.28 \\
\hline \multirow{3}{*}{ MIROC5 } & 2016-2043 & 162.25 & 37.52 & 151.56 & 28.46 \\
\hline & 2044-2071 & 156.32 & 32.49 & 159.71 & 35.37 \\
\hline & 2072-2099 & 134.84 & 14.28 & 136.91 & 16.04 \\
\hline \multirow{3}{*}{ MIROC-ESM } & 2016-2043 & 187.19 & 58.66 & 172.32 & 46.06 \\
\hline & 2044-2071 & 166.10 & 40.78 & 152.03 & 28.86 \\
\hline & 2072-2099 & 170.60 & 44.60 & 157.19 & 33.23 \\
\hline \multirow{3}{*}{ MPI-ESM-LR } & 2016-2043 & 138.11 & 17.06 & 118.30 & 0.27 \\
\hline & 2044-2071 & 135.10 & 14.51 & 140.50 & 19.09 \\
\hline & 2072-2099 & 134.65 & 14.13 & 154.13 & 30.64 \\
\hline \multirow{3}{*}{ MPI-ESM-MR } & 2016-2043 & 145.15 & 23.03 & 179.18 & 51.87 \\
\hline & 2044-2071 & 161.29 & 36.71 & 176.57 & 49.65 \\
\hline & 2072-2099 & 160.32 & 35.89 & 206.43 & 74.97 \\
\hline \multirow{3}{*}{ NORESM1-M } & 2016-2043 & 139.57 & 18.30 & 150.29 & 27.38 \\
\hline & 2044-2071 & 124.34 & 5.39 & 137.60 & 16.62 \\
\hline & 2072-2099 & 130.90 & 10.95 & 157.11 & 33.16 \\
\hline
\end{tabular}

\subsection{Impact of climate change on high flows}

In order to analyze the characteristics of high flows from the watershed, the ensemble 7-day high flows from 10 climate model outputs were analyzed with the help of box and whisker plots and compared with the historical 7-day high flows at USGS gage station \#03274000 (Figure 3). The 7-day high flow was determined by considering the highest value from the average of consecutive 7-day flow from each year. Our analysis suggested that the 7-day high flows would increase for the early and mid-century for both scenarios, whereas late century flow is expected to be slightly lower than that of mid-century for RCP 4.5. However, a clear and consistent increasing trend of 7-day high flows was observed under RCP 8.5. It is interesting to report that the interquartile range of the early century was relatively less compared to other periods in both scenarios.

In addition to 7-day high flows, actual 7-day, 10-year high flows (7Q10) were estimated by conducting statistical analysis. Figure 4 shows the graphical representation of computed 7Q10 high flows for the historical and future periods using climate output from 10 climate models. The analysis suggested that the CSIRO-MK3-6 model under the RCP 8.5 scenario predicted significantly higher $7 \mathrm{Q} 10$ in the early century $(104 \%)$, whereas it significantly predicted higher flows for the late century under RCP $4.5(130 \%)$. Similarly, MIROC5 and MPI-ESM-LR revealed relatively smaller 7Q10 values compared to other climate models under both scenarios. As a result, the ensemble 7Q10 from the simulated flows from 10 climate models did not significantly increase in the late century especially under RCP 4.5. However, the ensemble average 7Q10 for early and mid-century was found to be increasing by $42 \%$ under the RCP 4.5 scenario with a slightly decreasing trend in the late century $(29.4 \%)$. On the contrary, the 7Q10 flows computed using the RCP 8.5 scenario showed a consistently rising trend of $7 \mathrm{Q} 10$ for the 21 st century (early century- $43.1 \%$, mid-century- $49.8 \%$, and late-century- $65 \%$ ) with an average increase of $44.28 \%$.

\section{\begin{tabular}{l|l|l|l|}
$1988-2015$ & $2016-2043$ & $2044-2071$ & $2072-2099$
\end{tabular}}

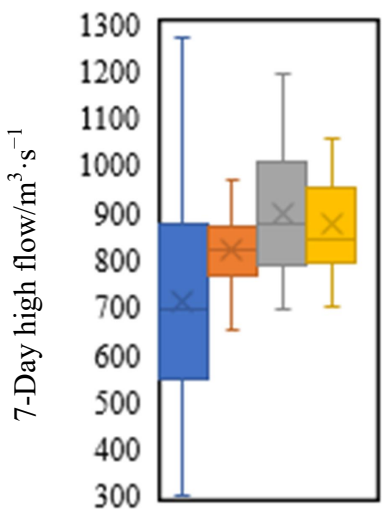

a. RCP 4.5

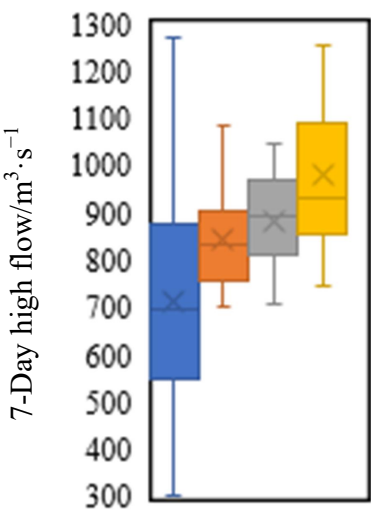

b. RCP 8.5
Figure 3 7-day high flows from the ensemble of 10 climate models and observed flows at USGS station \#03274000 under RCP 4.5 and RCP 8.5

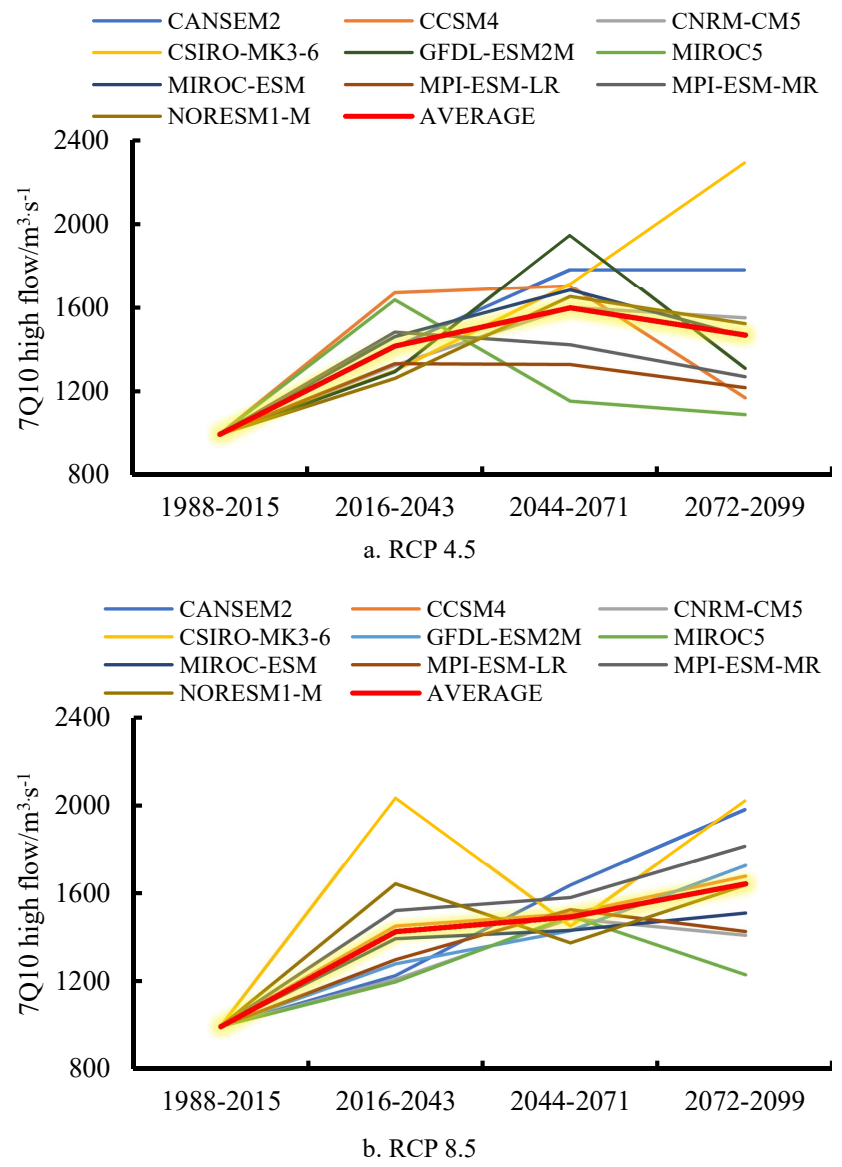

Figure 4 7Q10 high flows from 10 climate models and observed streamflow at USGS station \#03274000 under RCP 4.5 and RCP 8.5 
The annual peak flows (Figure 5) from the ensemble simulated flow from the SWAT model using 10 climate model outputs were analyzed. The analysis suggested that the annual peak flow would significantly increase in the late century compared to the historical period in both scenarios. While early and mid-century flows are not significantly different in both scenarios, RCP 8.5 revealed the increasing trend of annual peak compared to the historical period. This is not a surprising outcome as the RCP 8.5 is the highest emission scenario leading to the increased precipitation trend. Regardless, it is worthwhile to report that the interquartile range of future periods was less compared to the historical period indicating that the variability of climate output predicted by climate models was within a narrow range.
1988-2015 2016-2043

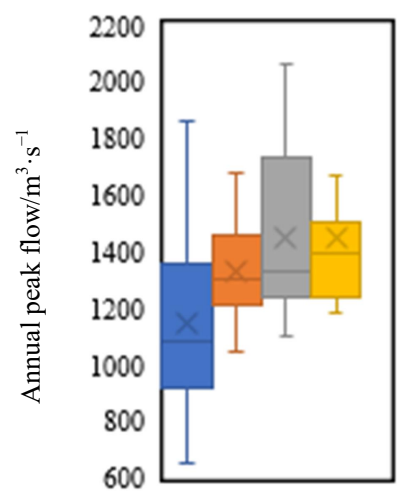

a. RCP 4.5
2044-2071 2072-2099

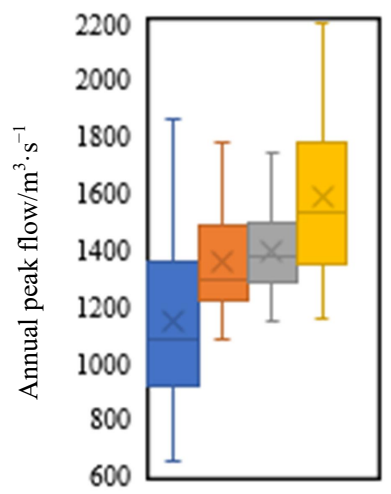

b. RCP 8.5
Figure 5 Annual peak flows from the ensemble of 10 climate models and observed streamflow at USGS station \#03274000 under RCP 4.5 and RCP 8.5

In addition, the monthly peak flow was computed for the entire simulation period, which is reported in Figure 6. The peak of each month from various years across the simulation period of the early, mid, and late-century were plotted using a box plot. No consistent pattern of monthly peak flows could be identified in the results. For example, there was a slightly increasing trend in the monthly peak in April and a distinct increasing trend in May, July, and August. Similarly, there was a slightly decreasing trend in January but the trend in February and March is somewhat vague and indistinct. The analysis revealed that variability, as shown through the box plots in Figure 6, is relatively less compared to the historical period in RCP 4.5 except for August and September.

This trend was consistent for RCP 8.5 (Figure 7) with additional amplification of monthly peak flows, especially during summer months including May, August, September, and October. Broadly, there are two patterns. One from May to October as an increasing trend except in June and the other is from November to April, which is constant. In fact, the increased flow in September concurs with the study conducted by Lettenmaier et al. ${ }^{[71]}$ who reported the increased historical precipitation from 1948 to 1988.

Flooding events with return periods 2-, 5-, 10-, 25-, 50-, 100-, 200 -, and 500-year were computed using the simulated streamflow at the basin outlet. Simulated flooding events from 10 climate models under RCP 4.5 and RCP 8.5 were compared against observed flooding events and percentage change was reported in box plots (Figure 8 and Figure 9). The median of the percentage change in each return period in the early century was comparable to the late century in RCP 4.5. However, the median percentage change in flooding events would be significantly higher in mid-century than that of other periods. It is worthwhile to mention that this increase in flow was computed based on median peak flow from the respective periods, which was computed through the streamflow using climate data from 10 climate models. In the RCP 8.5 scenario, the mid-century flood would increase for 2-, 5-, and 10-year return periods and decrease for 100-, 200-, and 500 -year. The late century flood change would be maximum with a significant increase in variability except for 25 -year return periods.

In order to realize how the peak flows in late century compares with the historical periods including early and mid-century, the peak flows taken average from 10 climate models for various return period under RCP 4.5 and RCP 8.5 were plotted in Figure 10 and Figure 11, respectively. The analyses of peak flows for respective return periods suggested that the early century peak would be higher than that of the baseline period, whereas the mid and late century peak flows would be almost similar but much higher than baseline and early peaks especially under RCP 4.5. It is interesting to note that the trends of peak flow on each return period were different under RCP 4.5 than RCP 8.5. In RCP 8.5, the peak flows in mid-century were very close to the peak flows in the early century and even smaller in return periods 50-, 100-, 200-, and 500-year. Nevertheless, the late century peak flow was expected to be significantly higher than the early and mid-century.

Since the Great Miami River Watershed comprises several dams and levees for flood protection, monthly high flows at the outlet of 4 major dams including Taylorsville, Germantown, Huffman, and Englewood were analyzed. The monthly peak outflows from each dam for historical and three future periods are presented in Figure 12 and Figure 13 for RCP 4.5 and RCP 8.5, respectively. In order to assess the reservoir response for the increased flow in the future, dams performances for the historical and future periods with the simulated flow using equal time intervals were assessed for apple to apple comparison. Among 10 climate models, our investigation depicted that model CISRO-MK 3.6 predicted mostly increased flows in the future, whereas models including MPI-ESM-LR and MIROC5 relatively predicted decreased flow. It was clearly noted from Figures 12 and 13 that the higher flows predicted from CISRO-MK 3.6 were in the summer period from May to September, especially in the late century. Similarly, monthly peak flow from each dam was projected to be higher in future periods, especially in January and May.

Since the increased daily flow due to climate change could be crucial in case the flow exceeds the dam and reservoir capacity, the frequency analysis of the increased daily peak flows was performed for future periods. To see the trend of outflow from the dams the 90th percentile of daily flows based on 10 climate models for the months of January, May, and September were analyzed. Since it is voluminous and inconvenient to report outflow from each climate model, only ensemble average streamflow using all climate model outputs was reported for conciseness. The results showed the 90th percentile flows would not show any consistent trend across the entire century under RCP 4.5. However, it was predicted that the 90th percentile flows would increase for all dams throughout the $21 \mathrm{st}$ century. The 90th percentile flow is maximum during the $2035 \mathrm{~s}$ period for all dams in the range of $19 \%$ to $43 \%$ during January under RCP 4.5 (not shown). Similarly, the study showed that the 90th percentile daily flows under RCP 4.5 would be highest in September during 2055s for all major dams in the increased range from $52 \%$ to $223 \%$. However, the flow would be maximum in May in the increased range of $45 \%$ to $72 \%$ during the period of 2085 s (not shown). 

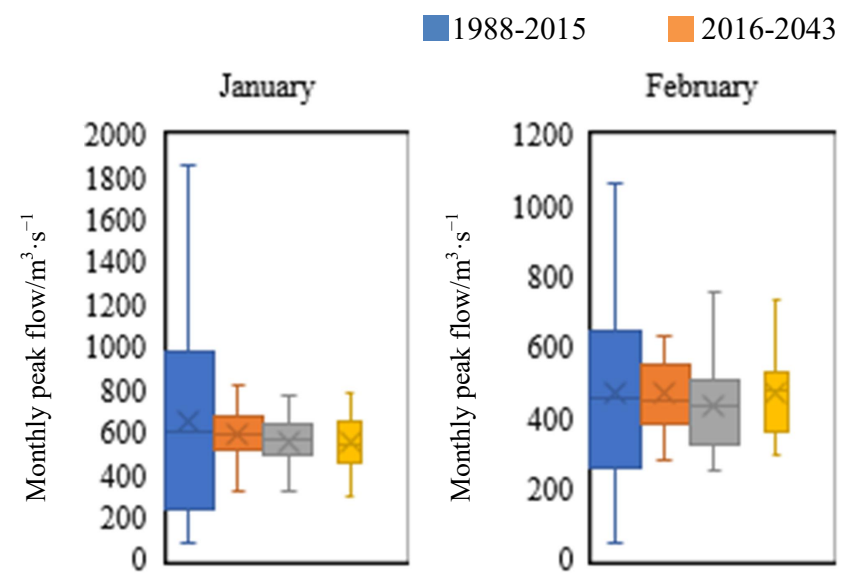

2044-2071 2072-2099
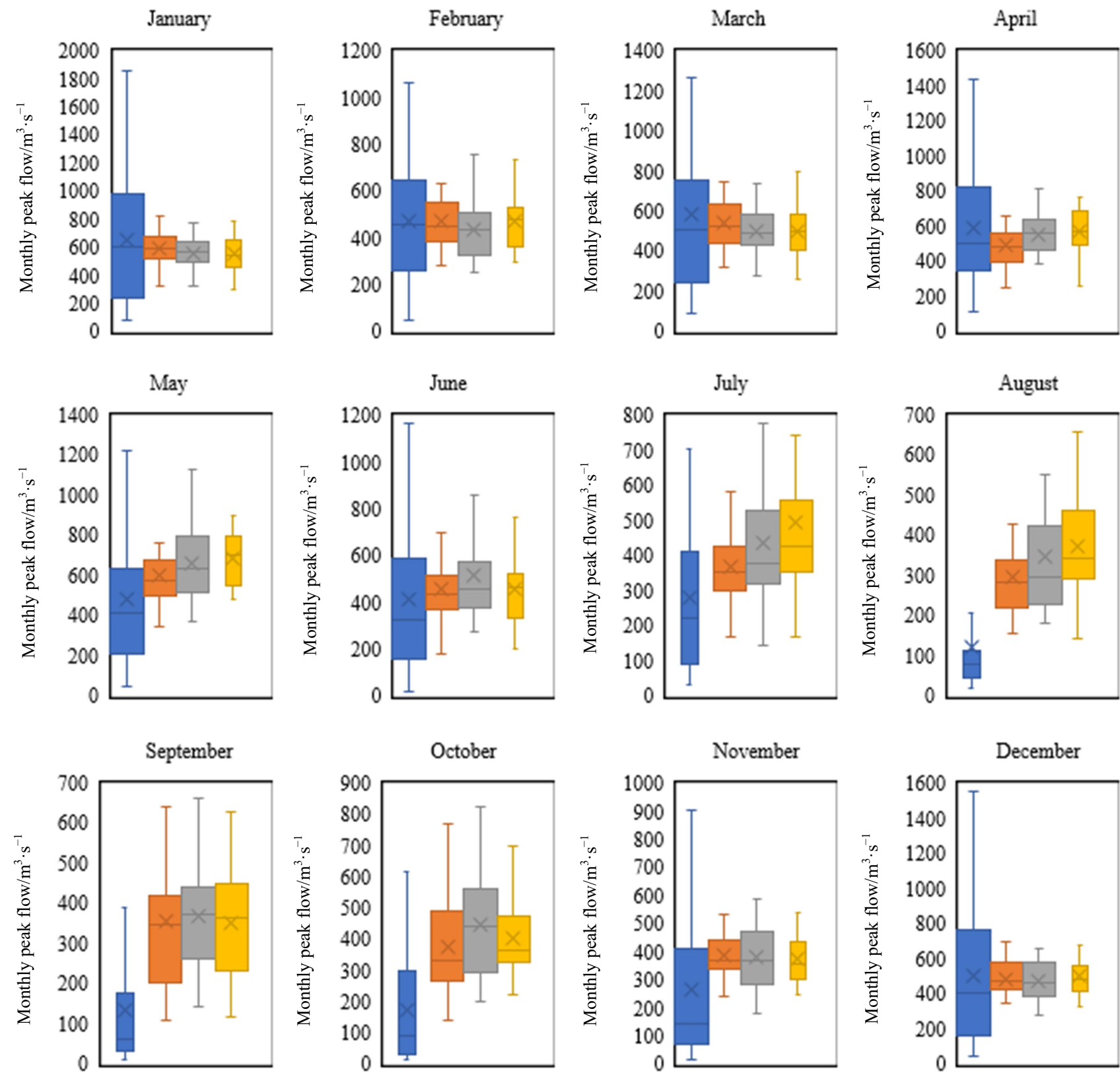

Figure 6 Monthly peak flows from the ensemble of 10 climate models and observed streamflow at USGS station \#03274000 under RCP 4.5 for various months

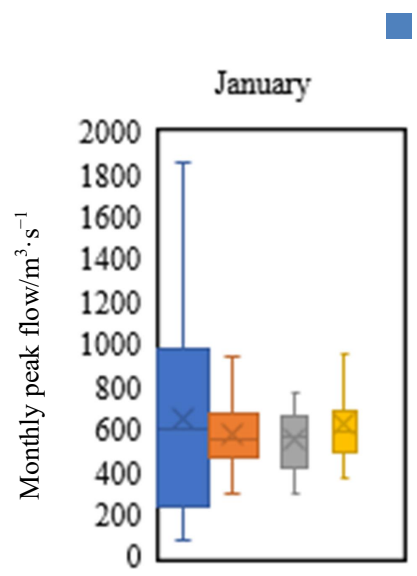

$1988-2015$

2016-2043


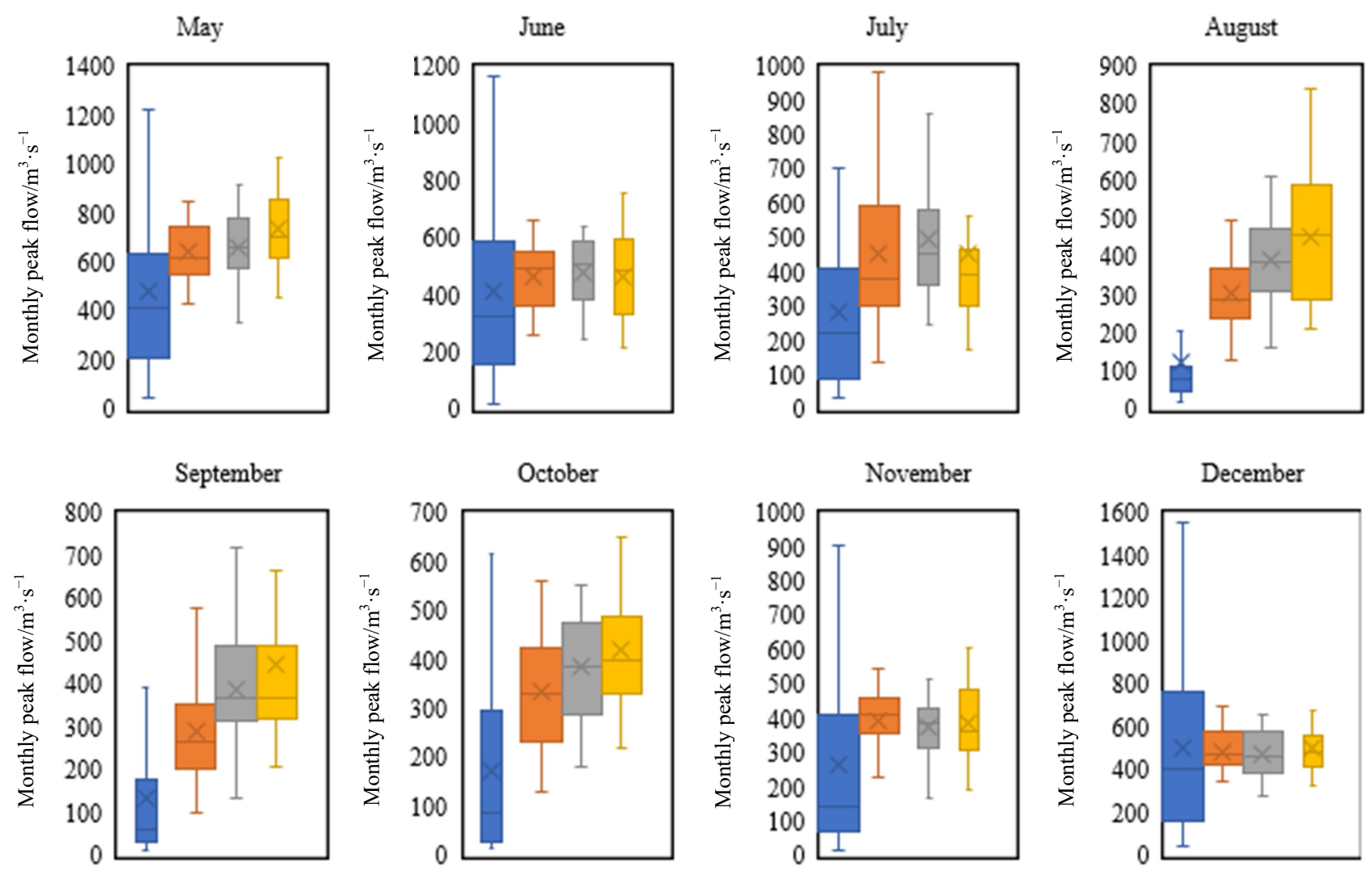

Figure 7 Monthly peak flows from the ensemble of 10 climate models and observed streamflow at USGS station \#03274000 under RCP 8.5
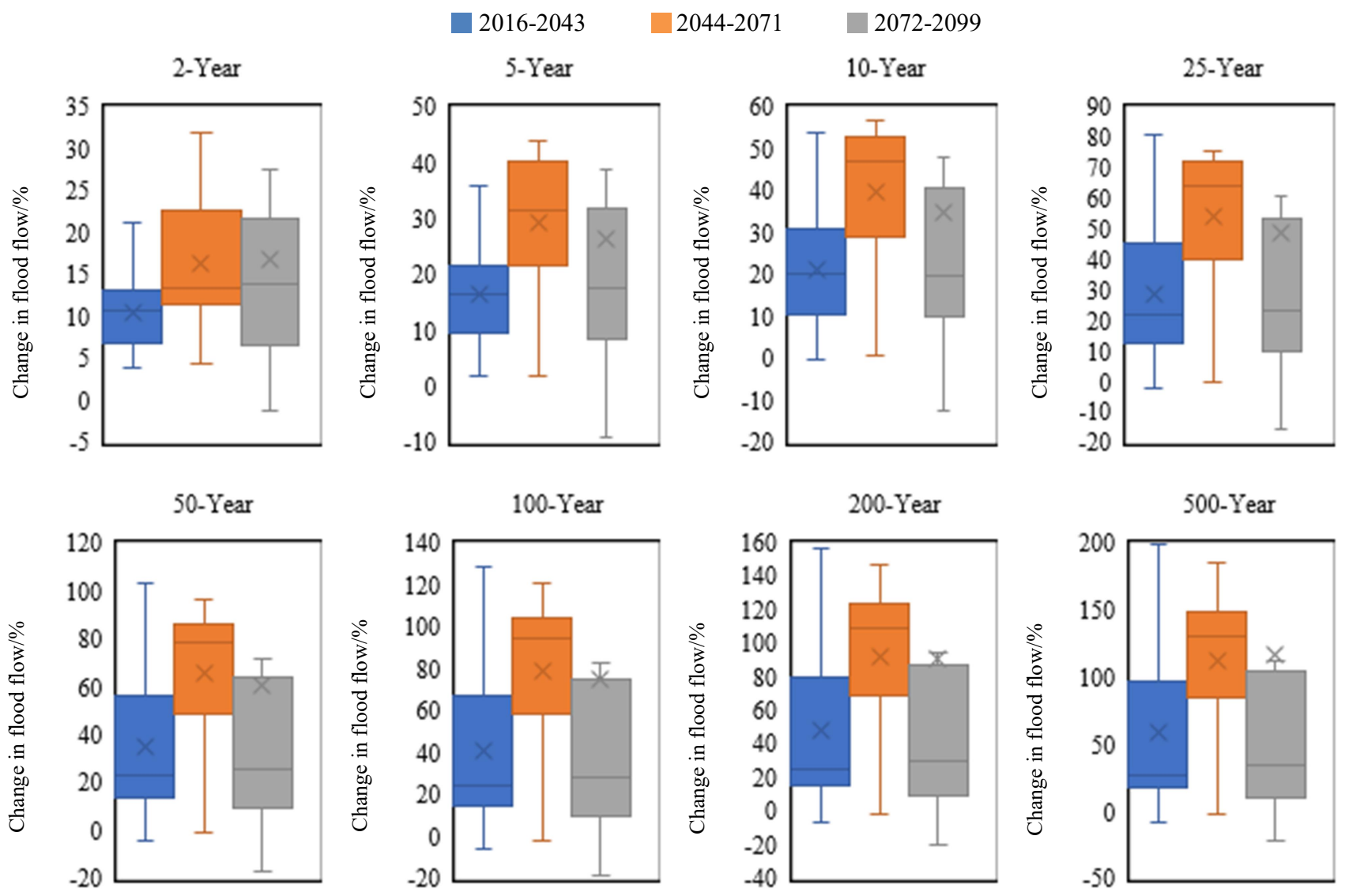

Figure 8 Change in flood magnitudes for recurrence intervals of 2-, 5-, 10-, 25-, 50-, 100-, 200-, and 500-year from the ensemble of 10 climate models with respect to the observed period at USGS station \#03274000 under RCP 4.5 


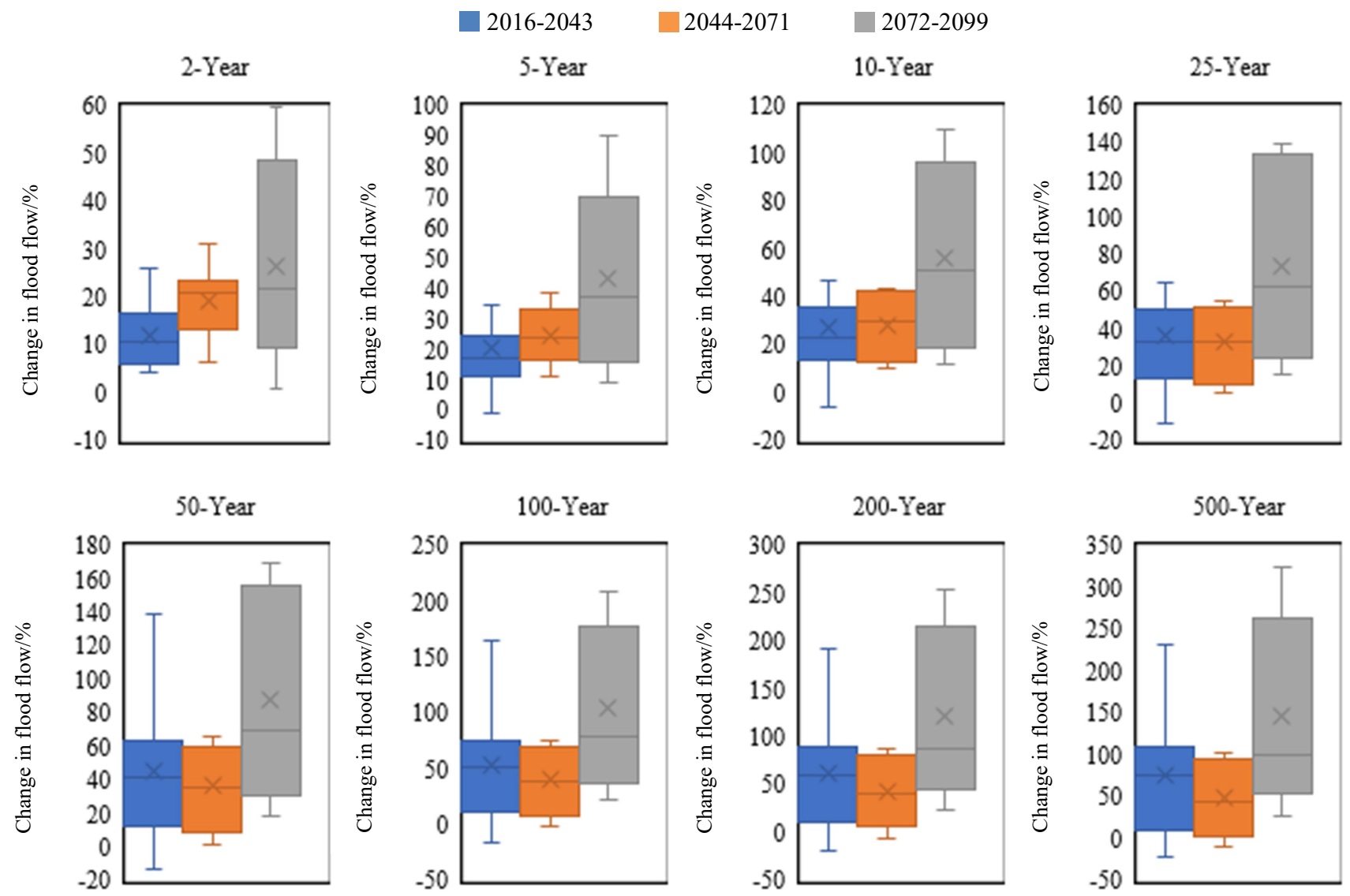

Figure 9 Change in flood magnitudes for recurrence intervals of 2-, 5-, 10-, 25-, 50-, 100-, 200-, and 500-year from the ensemble of 10 climate models with respect to the observed period at USGS station \#03274000 under RCP 8.5

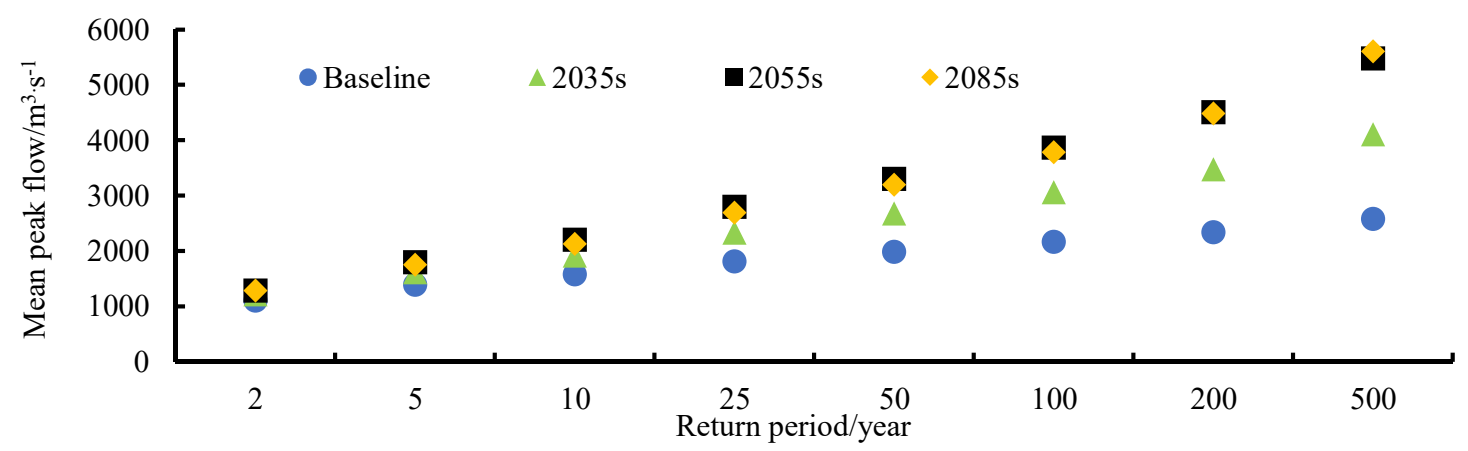

Figure 10 Mean peak flows for recurrence intervals of 2-, 5-, 10-, 25-, 50-, 100-, 200-, and 500-year after averaged from 10 climate models under RCP 4.5 for early, mid-, and late century with respect to the baseline period

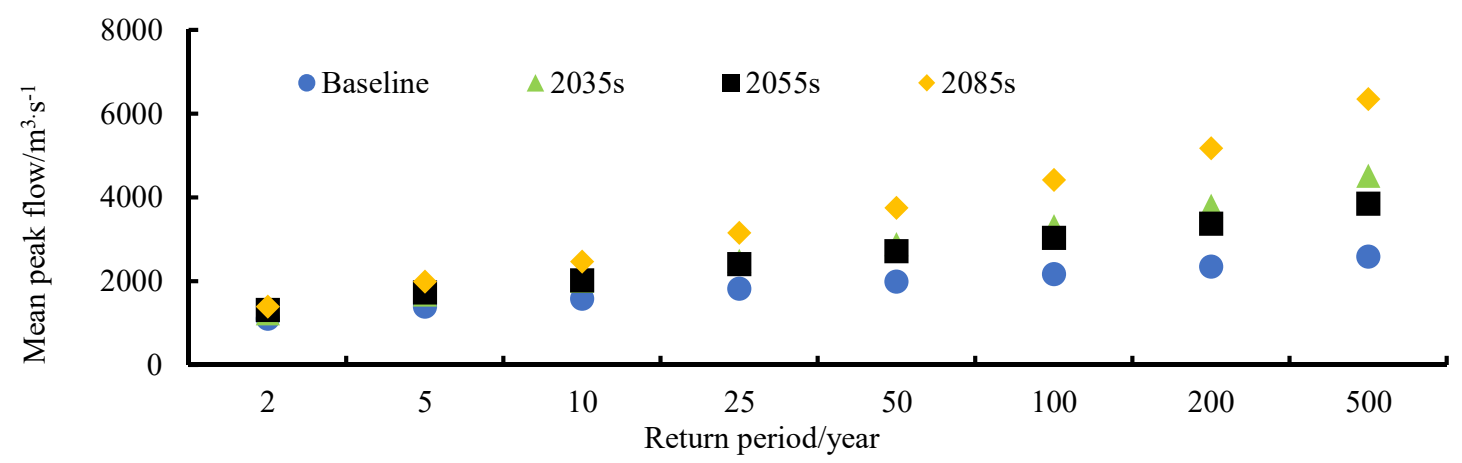

Figure 11 Mean peak flows for recurrence intervals of 2-, 5-, 10-, 25-, 50-, 100-, 200-, and 500-year after averaged from 10 climate models under RCP 8.5 for early, mid-, and late century with respect to the baseline period 

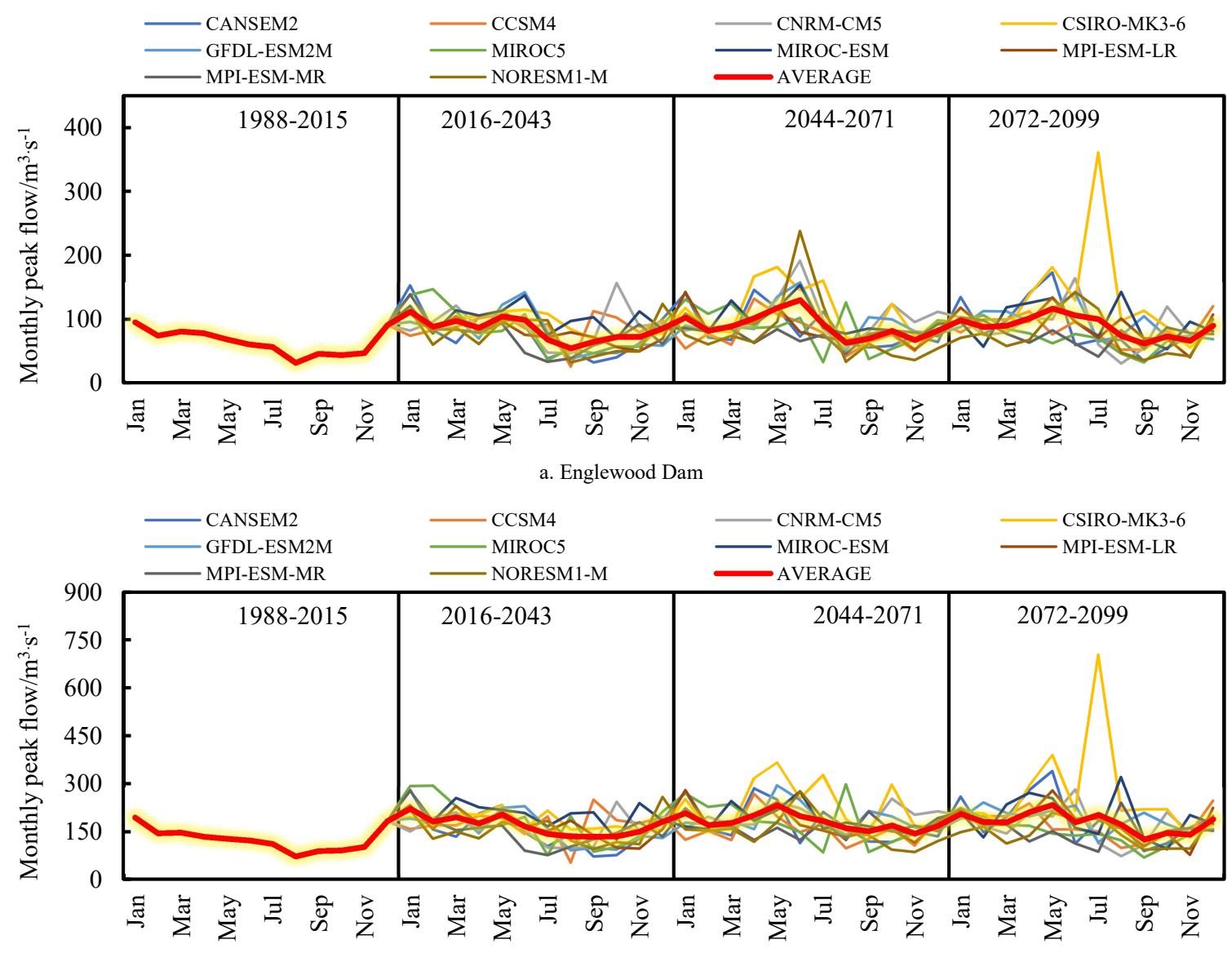

b. Taylorsville Dam



c. Huffman Dam

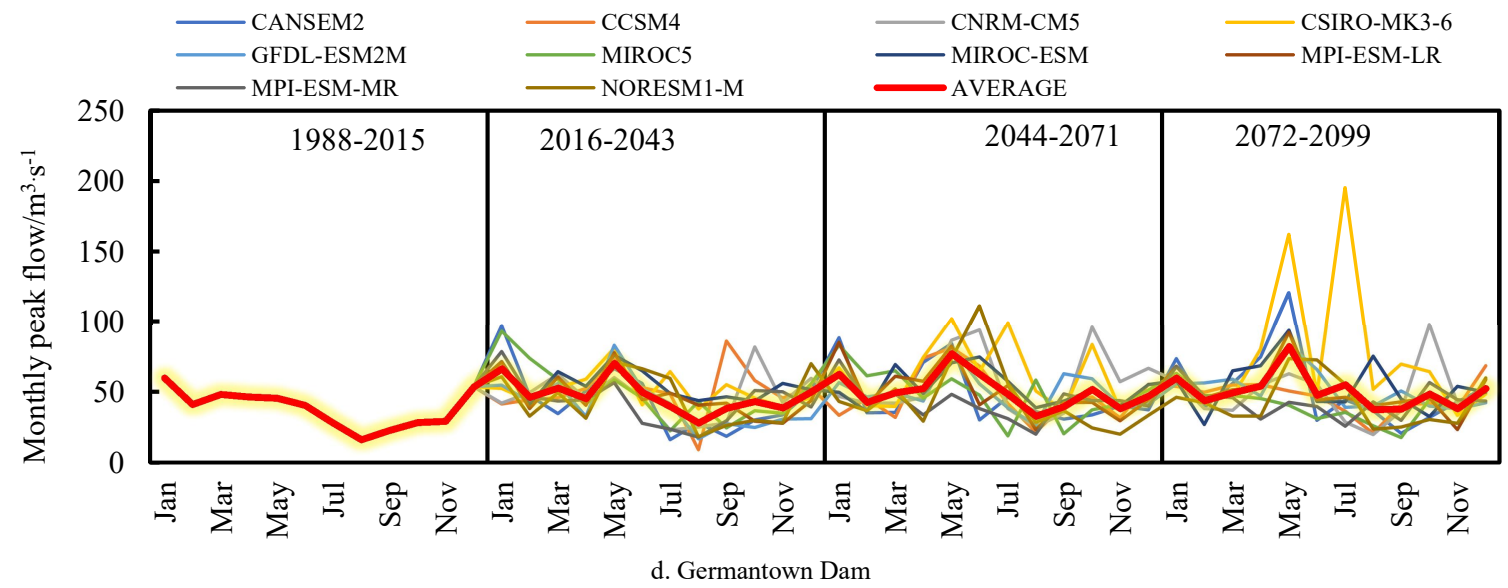

Figure 12 Monthly peak flows from 10 climate models under RCP 4.5 at Englewood Dam (a), Taylorsville Dam (b), Huffman Dam (c), and Germantown Dam (d) 


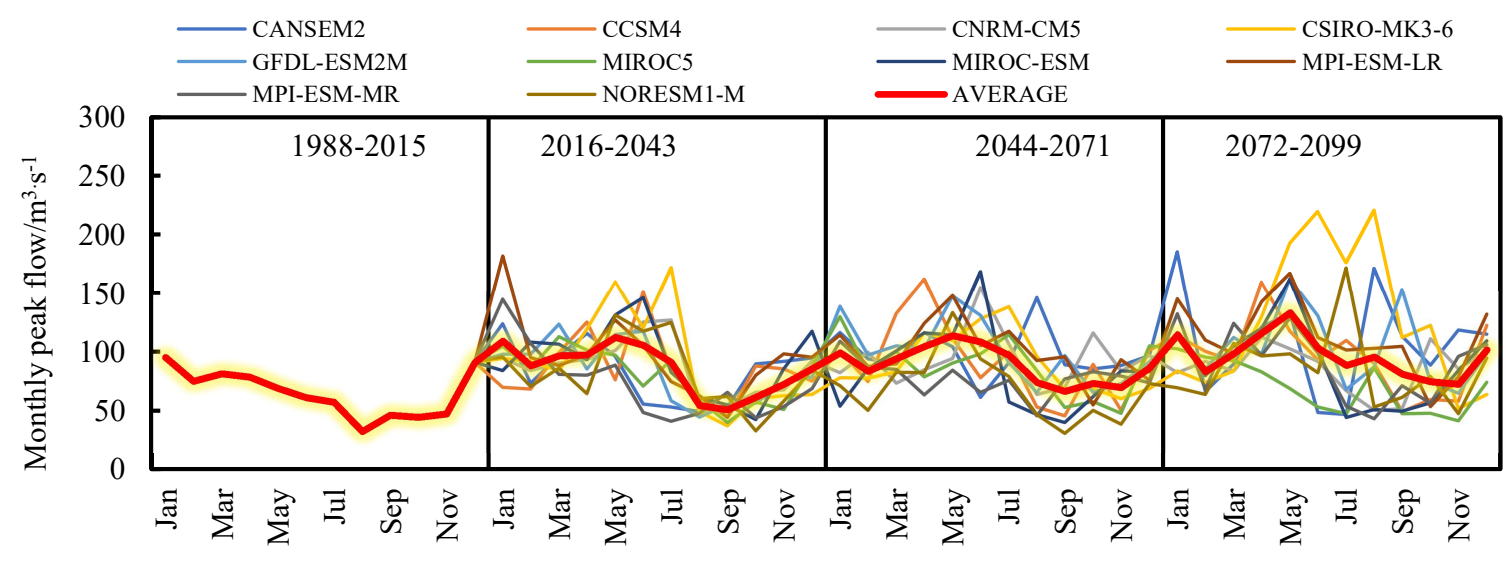

a. Englewood Dam

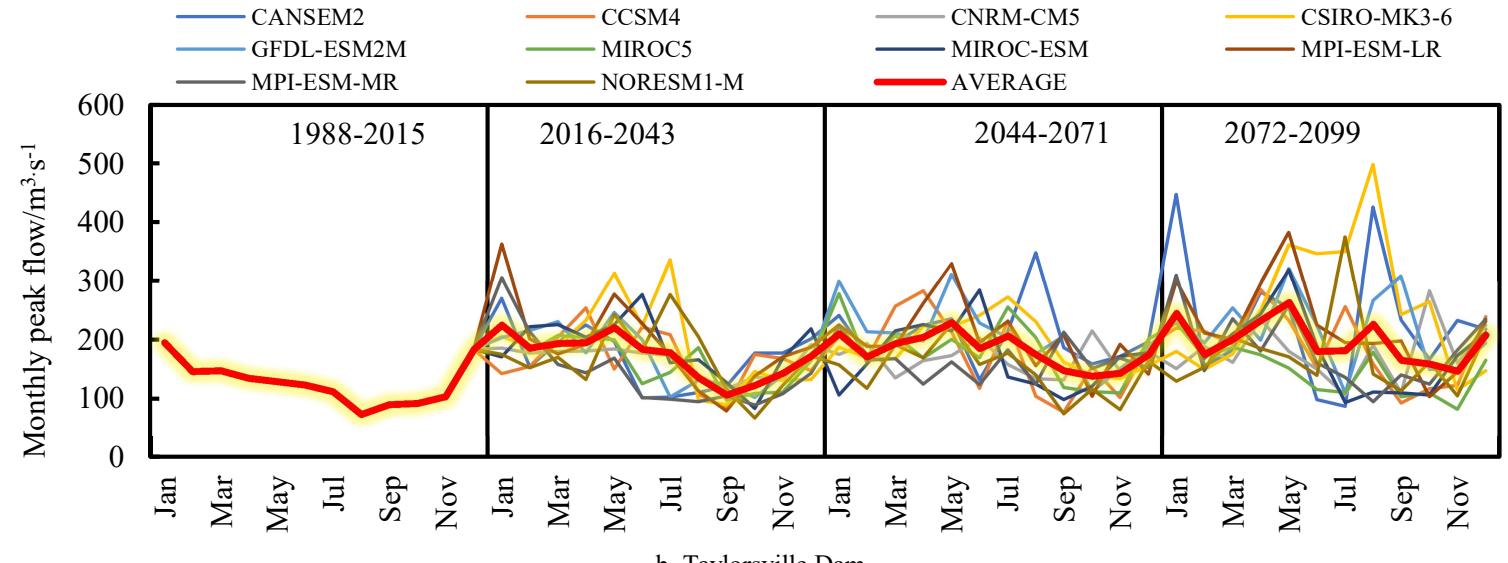

b. Taylorsville Dam

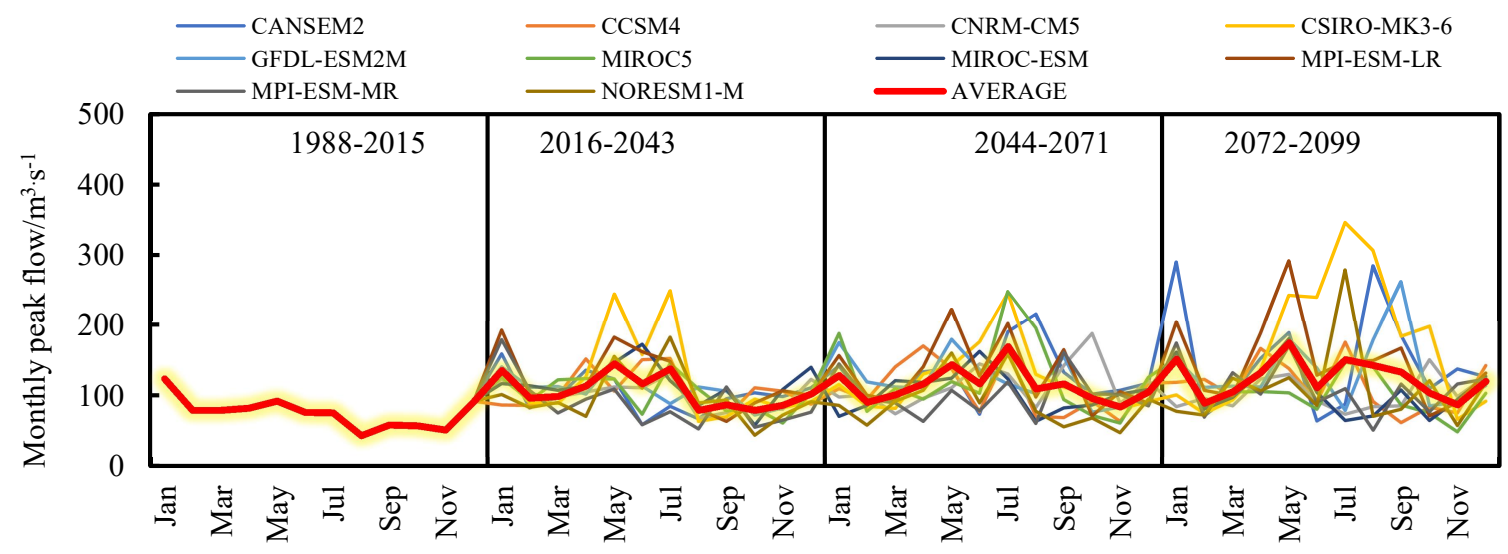

c. Huffman Dam

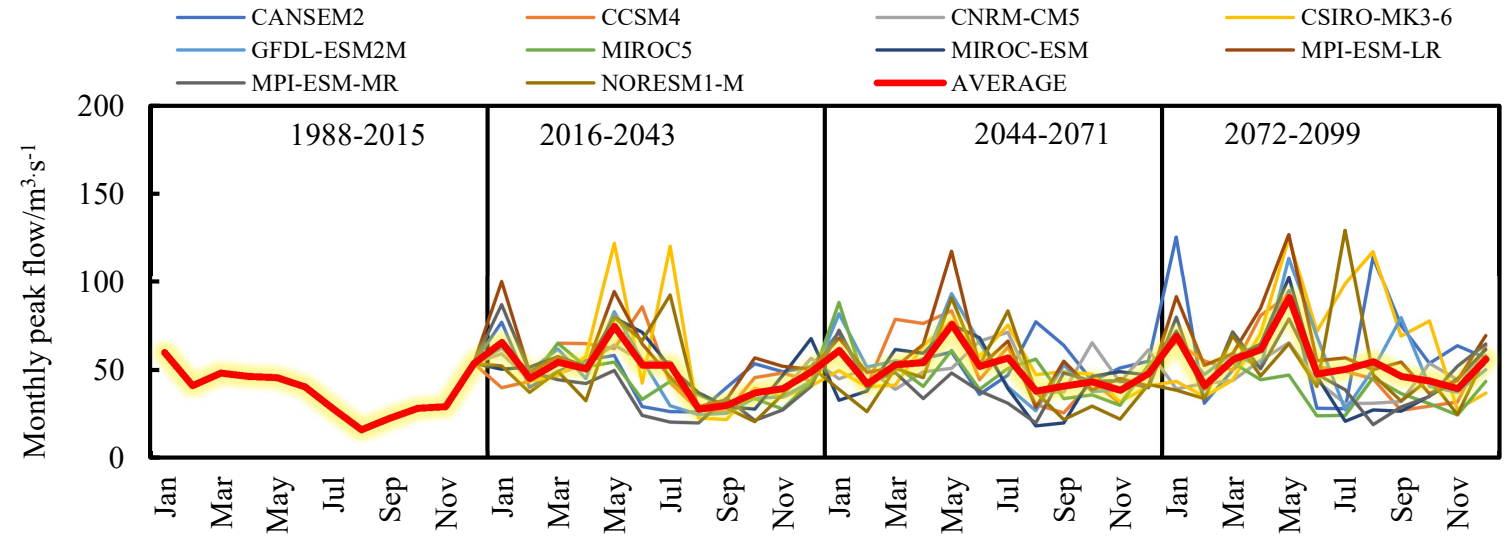

Figure 13 Monthly peak flows from 10 climate models under RCP 8.5 at Englewood Dam (a), Taylorsville Dam (b), Huffman Dam (c), and Germantown Dam (d) 
On the contrary, 90th percentile daily flows under RCP 8.5 showed a clear increasing trend in January, May, and September. In all dams, the biggest increase in the $90^{\text {th }}$ percentile flow would occur in the late century. The 90th percentile flow in dams for January (Figure 14) during the late century ranged from $44 \%$ to $70 \%$. While the 90th percentile daily flows in some dams during mid-century decreased by $2.5 \%$ and $3.5 \%$ from the early century (Figure 15), the maximum $90^{\text {th }}$ percentile daily flows would occur in the late century for all dams varying from $45 \%$ to $107 \%$. The considerable increase in the $90^{\text {th }}$ percentile daily flow was found to be in September varying in the range of $66 \%$ to $250 \%$ (Figure 16 ). Regardless, the month of September is the low flow period in Ohio; therefore, an additional increase of the flows in September of the late century would safely be accommodated in the reservoir as it is well below the reservoir capacity.

Overall, the findings of the research are consistent with the previous research ${ }^{[1]}$ suggesting that high flows would increase in the future especially in RCP 8.5. Even though the impact of climate change on streamflow is not consistent across the globe, the earlier findings ${ }^{[11]}$ also suggested the increase in flows in the USA. Regardless, the research findings, especially increasing peak flows and the frequency of peak flows, agree with the documented literature ${ }^{[49]}$



Figure 14 90th percentile flows from the ensemble of 10 climate models in January under RCP 8.5

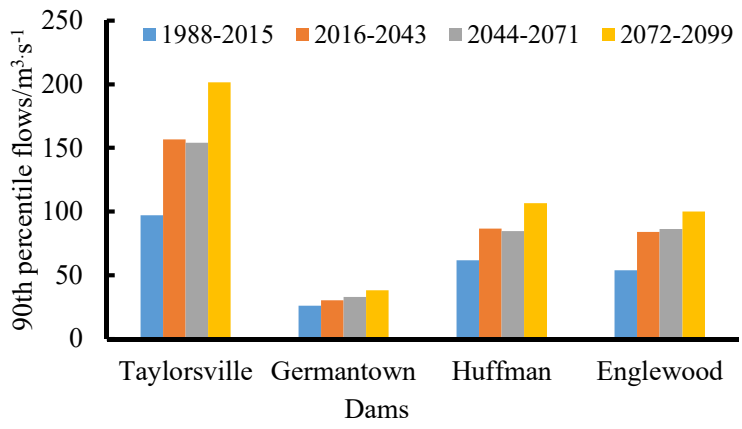

Figure 15 90th percentile flows from the ensemble of 10 climate models in May under RCP 8.5



Figure 16 90th percentile flows from the ensemble of 10 climate models in September under RCP 8.5

\section{Conclusions}

This study presented a comprehensive investigation of high flows through the systematic analysis of climate change's impact on a basin-scale study. The 10 CMIP5 climate models under two emission scenarios (RCP 4.5 and RCP 8.5 ) were utilized in order to drive the SWAT model and illustrate the impact of climate change on streamflow regimes, especially during high flow periods in the Great Miami River Watershed. The SWAT model, which adequately simulated streamflow, was utilized to simulate streamflow for the future after multi-sites calibration and validation. The coupling of hydrologic models with GCM projections was utilized to estimate streamflow in the subbasin outlets for the 21 st century.

The average annual streamflow at the watershed outlet from 10 climate models was projected to increase for all simulation periods $(2035 \mathrm{~s}, 2055 \mathrm{~s}$, and $2085 \mathrm{~s})$ under two emission scenarios - RCP 4.5 and RCP 8.5. The 7-day high flows from the ensemble of 10 climate models were estimated to increase in the future with reduced variability. The significant increase in peak flow as compared to the historical period was expected to occur in May, July, August, September, and October. Similarly, 7Q10 high flows showed a significant upward trend in the future especially for RCP 8.5. The analysis was also conducted to investigate the possible increase in the flood frequency in the future for various return periods including 2-, 5-, 10-, 50-, 100-, 200-, and 500-year compared to historical flood frequency. Under RCP 4.5, the change in flood magnitude will be higher during mid-century, whereas under RCP 8.5 , the change in flood magnitude will be more in the late century.

The climate change effects in reservoirs were quantified in terms of monthly peak flows. Four major dams-Taylorsville, Germantown, Huffman, and Englewood in the watershed showed increased monthly peak flow during each simulation period. The change in peak flows varied depending on the climate models. The CISRO-MK 3.6 showed generally increased peak flows, whereas MPI-ESM-LR and MIROC5 projected the decreased peak flows. In addition, the $90^{\text {th }}$ percentile exceedance flow from the reservoir outlets also increased in the future even though it was not consistent across all months. A significant increase in the $90^{\text {th }}$ percentile flow was projected in Englewood dam in September in the mid- and late-century compared to the historical and early century flow. While a distinct trend was not detected under RCP 4.5 , the increase in flows from the dam was detected under RCP 8.5 especially during January, May, and September. While this study found a modest increase in reservoir discharge, especially for monthly averages flows, the daily flow from each dam significantly exceeded in the future period.

Even though it is expected to increase high flows in the $21 \mathrm{st}$ century, the projected streamflow presented in this analysis can inherit some degree of uncertainty due to various reasons. For example, the likelihood of flooding due to sedimentation in the reservoir was not considered for this study. In general, the findings indicate that the increase of high flows is anticipated for the 21 st century. These long-term hydrologic predictions using projected climate data may provide the basis for the water resources managers or decision-makers to develop flood regulating strategies, especially when there is a likelihood of overflow of the flood regulating reservoir. 


\section{[References]}

[1] Leta O T, El-Kadi A I, Dulai H, Ghazal K A. Assessment of climate change impacts on water balance components of Heeia watershed in Hawaii. Journal of Hydrology: Regional Studies, 2016; 8: 182-197.

[2] Shrestha N K, Du X, Wang J. Assessing climate change impacts on fresh water resources of the Athabasca River Basin, Canada. Science of the Total Environment, 2017; 601: 425-440.

[3] Bernstein L, Bosch P, Canziani O, Chen Z, Christ R, Davidson O, et al. Climate change 2007: Synthesis report: An assessment of the intergovernmental panel on climate change. Environmental Policy, 2008; 27(2): 408. doi: 10.1111/j.1728-4457.2001.00203.x.

[4] de Larminat P. Earth climate identification vs. anthropic global warming attribution. Annual Reviews in control, 2016; 42: 114-125.

[5] Elferchichi A, Giorgio G A, Lamaddalena N, Ragosta M, Telesca V. Variability of temperature and its impact on reference evapotranspiration: The test case of the Apulia Region (Southern Italy). Sustainability, 2017; 9(12): 2337 . doi: 10.3390/su9122337.

[6] Hansen J, Sato M, Ruedy R, Lo K, Lea D W, Medina-Elizade M. Global temperature change. Proceedings of the National Academy of Sciences, 2006; 103(39): 14288-14293.

[7] Vitousek P M, Mooney H A, Lubchenco J, Melillo J M. Human domination of Earth's ecosystems. Science, 1997; 277(5325): 494-499.

[8] Graham S, Parkinson C, Chahine M. The Water Cycle, NASA Earth Obs, Greenbelt, $\quad$ Md. $2010 . \quad$ Available: http://earthobservatory.nasa.gov/Features/Water/. Accessed on [2016-12-01].

[9] Arnell N W. Effects of IPCC SRES* emissions scenarios on river runoff: A global perspective. Hydrology \& Earth System Sciences, 2003; 7(5): 619-641.

[10] Döll P, Zhang J. Impact of climate change on freshwater ecosystems: A global-scale analysis of ecologically relevant river flow alterations. Hydrology \& Earth System Sciences Discussions, 201; 14: 783-799.

[11] Arnell N W, Gosling S N. The impacts of climate change on river flow regimes at the global scale. Journal of Hydrology, 2013; 486: 351-364.

[12] Bhandari S, Thakur B, Kalra A, Miller W P, Lakshmi V, Pathak P. Streamflow forecasting using singular value decomposition and support vector machine for the upper Rio Grande River Basin. JAWRA Journal of the American Water Resources Association, 2019; 55(3): 680-699.

[13] Cherkauer K A, Sinha T. Hydrologic impacts of projected future climate change in the Lake Michigan region. Journal of Great Lakes Research, 2010; 36: 33-50.

[14] Xu Y P, Zhang X, Ran Q, Tian Y. Impact of climate change on hydrology of upper reaches of Qiantang River Basin, East China. Journal of Hydrology, 2013; 483: 51-60.

[15] Chattopadhyay S, Edwards D R, Yu Y, Hamidisepehr A. An assessment of climate change impacts on future water availability and droughts in the Kentucky River Basin. Environmental Processes, 2017; 4(3): 477-507.

[16] Choi W, Pan F, Wu C. Impacts of climate change and urban growth on the streamflow of the Milwaukee River (Wisconsin, USA). Regional environmental change, 2017; 17(3): 889-899.

[17] Roth V, Lemann T, Zeleke G, Subhatu A T, Nigussie T K, Hurni H. Effects of climate change on water resources in the upper Blue Nile Basin of Ethiopia. Heliyon, 2018; 4(9): e00771. doi: 10.1016/ j.heliyon.2018.e00771.

[18] Kang B, Ramírez J A. Response of streamflow to weather variability under climate change in the Colorado Rockies. Journal of Hydrologic Engineering, 2007; 12(1): 63-72.

[19] Jiang T, Chen Y D, Xu C Y, Chen X, Chen X, Singh V P. Comparison of hydrological impacts of climate change simulated by six hydrological models in the Dongjiang Basin, South China. Journal of Hydrology, 200; 336(3-4): 316-333.

[20] Kundzewicz Z W, Hirabayashi Y, Kanae S. River floods in the changing climate-observations and projections. Water Resources Management, 2010; 24(11): 2633-2646.

[21] Tian Y, Xu Y P, Zhang X J. Assessment of climate change impacts on river high flows through comparative use of GR4J, HBV and Xinanjiang models. Water resources management, 2013; 27(8): 2871-2888.

[22] Mohammed K, Saiful Islam A K, Tarekul Islam G M, Alfieri L, Bala S K, Uddin Khan M J. Impact of high-end climate change on floods and low flows of the Brahmaputra River. Journal of Hydrologic Engineering, 2017; 22(10): 04017041. doi: 10.1061/(ASCE)HE.1943-5584.0001567.

[23] Kelly S A, Takbiri Z, Belmont P, Foufoula-Georgiou E. Human amplified changes in precipitation-runoff patterns in large river basins of the Midwestern United States. Hydrology and Earth System Sciences Discussions, 2016; 11: 1-43.

[24] Byun K, Chiu C M, Hamlet A F. Effects of 21 st century climate change on seasonal flow regimes and hydrologic extremes over the Midwest and Great Lakes region of the US. Science of the Total Environment, 2019; 650: 1261-1277

[25] Pathak P, Kalra A, Ahmad S. Analyzing long-term changes in precipitation and temperature in the midwest United States. InWorld Environmental and Water Resources Congress 2016, 2016; pp.488-497.

[26] Villarini G, Scoccimarro E, Gualdi S. Projections of heavy rainfall over the central United States based on CMIP5 models. Atmospheric Science Letters, 2013; 14(3): 200-205.

[27] Panagopoulos Y, Gassman P W, Arritt R W, Herzmann D E, Campbell T D, Valcu A, et al. Impacts of climate change on hydrology, water quality and crop productivity in the Ohio-Tennessee River Basin. Int J Agric \& Biol Eng, 2015; 8(3): 36-53.

[28] Gupta S C, Baeumler N W, Kessler A C, Brown M K, Schuh W M, Wolf K A. Increased precipitation as the main driver of increased streamflow in tile-drained watersheds of the upper Midwestern US. Transactions of the ASABE, 2018; 61(1): 207-222.

[29] Zobel Z, Wang J, Wuebbles D J, Kotamarthi V R. Analyses for high-resolution projections through the end of the 21st century for precipitation extremes over the United States. Earth's Future, 2018; 6(10) 1471-1490.

[30] Bartels R J, Black A W, Keim B D. Trends in precipitation days in the United States. International Journal of Climatology, 2020; 40(2): 10381048.

[31] Papalexiou S M, Montanari A. Global and regional increase of precipitation extremes under global warming. Water Resources Research, 2019; 55(6): 4901-4914.

[32] Gao X, Schlosser C A. Mid-western US heavy summer-precipitation in regional and global climate models: the impact on model skill and consensus through an analogue lens. Climate Dynamics, 2019 Feb 15; 52(3-4): 1569-1582.

[33] Wu S Y. Potential impact of climate change on flooding in the Upper Great Miami River Watershed, Ohio, USA: a simulation-based approach. Hydrological Sciences Journal-Journal des Sciences Hydrologiques, 2010; 55(8): 1251-1263.

[34] Chien H, Yeh P J, Knouft J H. Modeling the potential impacts of climate change on streamflow in agricultural watersheds of the Midwestern United States. Journal of Hydrology, 2013; 491: 73-88.

[35] Winkler J A. Selection of climate information for regional climate change assessments using regionalization techniques: an example for the Upper Great Lakes Region, USA. International Journal of Climatology, 2015; 35(6): 1027-1040.

[36] Walters K M, Babbar-Sebens M. Using climate change scenarios to evaluate future effectiveness of potential wetlands in mitigating high flows in a Midwestern US watershed. Ecological Engineering, 2016; 89: 80 102.

[37] Sunde M G, He H S, Hubbart J A, Urban M A. An integrated modeling approach for estimating hydrologic responses to future urbanization and climate changes in a mixed-use midwestern watershed. Journal of Environmental Management, 2018; 220: 149-162.

[38] Bhandari S, Kalra A, Tamaddun K, Ahmad S. Relationship between ocean-atmospheric climate variables and regional streamflow of the conterminous United States. Hydrology, 2018; 5(2): 30 . doi: 10.3390/hydrology5020030.

[39] Milly P C, Dunne K A, Vecchia A V. Global pattern of trends in streamflow and water availability in a changing climate. Nature, 2005; 438(7066): 347-350.

[40] Pryor S C, editor. Climate change in the Midwest: impacts, risks, vulnerability, and adaptation. Indiana University Press; 2013; 266p.

[41] Githui F, Gitau W, Mutua F, Bauwens W. Climate change impact on SWAT simulated streamflow in western Kenya. International Journal of Climatology: A Journal of the Royal Meteorological Society, 2009; 29(12): 1823-1834.

[42] Faramarzi M, Abbaspour K C, Vaghefi S A, Farzaneh M R, Zehnder A J, Srinivasan $\mathrm{R}$, et al. Modeling impacts of climate change on freshwater availability in Africa. Journal of Hydrology, 2013; 480: 85-101.

[43] Acharya A. Quantification of modeled streamflows under climate change over the flint river watershed in Northern Alabama. Journal of Hydrologic Engineering, 2017; 22(9): 04017032. doi: 10.1061/(ASCE)HE.1943-5584.0001549. 
[44] de Oliveira V A, de Mello C R, Viola M R, Srinivasan R. Assessment of climate change impacts on streamflow and hydropower potential in the headwater region of the Grande river basin, Southeastern Brazil. International Journal of Climatology, 2017; 37(15): 5005-5023.

[45] Reshmidevi T V, Kumar D N, Mehrotra R, Sharma A. Estimation of the climate change impact on a catchment water balance using an ensemble of GCMs. Journal of Hydrology, 2018; 556: 1192-1204.

[46] Shiferaw H, Gebremedhin A, Gebretsadkan T, Zenebe A. Modelling hydrological response under climate change scenarios using SWAT model: the case of Ilala watershed, Northern Ethiopia. Modeling Earth Systems and Environment, 2018; 4(1): 437-449.

[47] Sowjanya P N. Intra-and interannual streamflow variations of Wardha watershed under changing climate. ISH Journal of Hydraulic Engineering, 2018; 19: 1-2.

[48] Eum H I, Vasan A, Simonovic S P. Integrated reservoir management system for flood risk assessment under climate change. Water Resources Management, 2012; 26(13): 3785-3802.

[49] Li L, Xu H, Chen X, Simonovic S P. Streamflow forecast and reservoir operation performance assessment under climate change. Water Resources Management, 2010; 24(1): 83-104.

[50] Ashofteh P S, Haddad O B, A. Mariño M. Climate change impact on reservoir performance indexes in agricultural water supply. Journal of Irrigation and Drainage Engineering, 2013; 139(2): 85-97.

[51] Eum H I, Simonovic S P. Integrated reservoir management system for adaptation to climate change: the Nakdong River Basin in Korea. Water Resources Management, 2010; 24(13): 3397-3417.

[52] Lauri H, De Moel H, Ward P J, Räsänen T A, Keskinen M, Kummu M. Future changes in Mekong River hydrology: impact of climate change and reservoir operation on discharge. Hydrol. Earth Syst. Sci. Discuss, 2012; 9(5): 6569-6614.

[53] Zhou Y, Guo S. Incorporating ecological requirement into multipurpose reservoir operating rule curves for adaptation to climate change. Journal of Hydrology, 2013; 498: 153-164.

[54] Men B, Liu H, Tian W, Wu Z, Hui J. The impact of reservoirs on runoff under climate change: A case of Nierji reservoir in China. Water, 2019; 11(5): 1005 . doi: 10.3390/w1 1051005 .

[55] Kharin V V, Zwiers F W. Estimating extremes in transient climate change simulations. Journal of Climate, 200; 18(8): 1156-1173.

[56] Wang J, Zhang X. Downscaling and projection of winter extreme daily precipitation over North America. Journal of Climate, 2008; 21(5): 923937.

[57] Christensen N S, Lettenmaier D P. A multimodel ensemble approach to assessment of climate change impacts on the hydrology and water resources of the Colorado River Basin. Hydrology and Earth System Sciences, 11(4): 1417-1434.

[58] Shrestha S, Sharma S, Gupta R, Bhattarai R. Impact of global climate change on stream low flows: A case study of the Great Miami River watershed, Ohio, USA. Int J Agric \& Biol Eng, 2019; 12(1): 84-95.

[59] Miami Conservancy District. 2018 Annual Report, 2018; 118p.

[60] Neitsch S L, Arnold J G, Kiniry J R, Williams J R. Soil and water assessment tool theoretical documentation version 2009. Texas Water Resources Institute, 2011; 647p.

[61] Abbaspour K C. SWAT-CUP 2012. SWAT Calibration and uncertainty program-A user manual, 2014; 106p.

[62] Nash J E, Sutcliffe J V. River flow forecasting through conceptual models part I-A discussion of principles. Journal of Hydrology, 1970; 10(3): 282-290.

[63] Moriasi D N, Arnold J G, Van Liew M W, Bingner R L, Harmel R D, Veith T L. Model evaluation guidelines for systematic quantification of accuracy in watershed simulations. Transactions of the ASABE, 2007; 50(3): 885-900.

[64] Brekke L, Thrasher B, Maurer E, Pruitt T. Downscaled CMIP3 and CMIP5 climate and hydrology projections: Release of downscaled CMIP5 climate projections, comparison with preceding information, and summary of user needs. 20 US Dept. of the Interior, Bureau of Reclamation, Technical Services Center, Denver, Colorado, 2013.

[65] Pachauri R K, Allen M R, Barros V R, Broome J, Cramer W, Christ R, et al. Climate change 2014: synthesis report. Contribution of working groups I, II and III to the fifth assessment report of the intergovernmental panel on climate change. Journal of Romance Studies, 2014; 4(2): 85-88.

[66] Maurer E P, Hidalgo H G. Utility of daily vs. monthly large-scale climate data: an intercomparison of two statistical downscaling methods. Hydrology and Earth System ences, 2008; 12(2): 551-563.

[67] Ines A V, Hansen J W. Bias correction of daily GCM rainfall for crop simulation studies. Agricultural and Forest Meteorology, 2006; 138(1-4): 44-53.

[68] Li H, Sheffield J, Wood E F. Bias correction of monthly precipitation and temperature fields from Intergovernmental Panel on Climate Change AR4 models using equidistant quantile matching. Journal of Geophysical Research: Atmospheres, 2010; 115(D10). doi: 10.1029/2009JD012882.

[69] United States Environmental Protection Agency. Technical support document for water quality-based toxics control. Washington DC: USEPA Office of Water, 1985; EPA/440/4-85-032.

[70] Flynn K M, Kirby W H, Hummel P R. User's manual for program PeakFQ, annual flood-frequency analysis using Bulletin 17B guidelines, 2006; 38p.

[71] Lettenmaier D P, Wood E F, Wallis J R. Hydro-climatological trends in the continental United States, 1948-88. Journal of Climate, 1994; 7(4): 586-607.

[72] Sharma S, Shrestha A, Mclean C E. Impact of global climate change on stream low flows in a hydraulic fracking affected watershed. Journal of Water Resource and Hydraulic Engineering, 2016; 5: 1-19. 